\title{
SPI1 wt Allele
}

National Cancer Institute

\section{Source}

National Cancer Institute. SPI1 wt Allele. NCI Thesaurus. Code C52874.

The human SPI1 wild-type allele is located in the vicinity of $11 \mathrm{p} 11.2$ and is approximately $24 \mathrm{~kb}$ in length. This allele, which encodes transcription factor PU.1 protein, is involved in the activation of transcription by RNA polymerase II. 